\title{
Characteristics of pediatric intensive care residency programs in Argentina. A national survey
}

\author{
Martín Truszkowski, M.D. ${ }^{a}$, Rodolfo P. Moreno, M.D. ${ }^{a}$, Silvia N. Santos, M.D. ${ }^{a}$, \\ Guillermo E. Moreno, M.D. ${ }^{a}$, Thomas Iolster, M.D. ${ }^{a}$, Alejandro Siaba Serrate, M.D. ${ }^{b}$, \\ Luis Landry, M.D. ${ }^{a, b}$, María Elena Ratto, M.D. ${ }^{b}$, Daniel Rufach, M.D. ${ }^{a}$, \\ Analía Fernández, M.D. ${ }^{b}$, Juan C. Vassallo, M.D. ${ }^{a}$, Daniel Buamscha, M.D. ${ }^{a}$, \\ Gustavo Debaisi, M.D. ${ }^{a}$, HoracioYulitta, M.D. ${ }^{c}$ and Clinical and Epidemiological \\ Research Group in Pediatric Intensive Cared
}

\section{ABSTRACT}

Introduction. Pediatric intensive care residency programs have been in place in Argentina forjust a few years. Knowing their status offers the possibility to establish strategies to help with professional development and training.

Objectives. 1) To describe the characteristics of pediatric intensive care residency programs across Argentina. 2) To assess whether certain characteristics are related to a higher vacancy filling rate. 3) To assess job placement in the hospital where residents are trained.

Design. Descriptive, observational study. National survey.

Inclusion criteria. Pediatric intensive care residency programs in place between April $1^{\text {st }}$, 2014 and May 31 $1^{\text {st }}, 2014$.

a. National Committee of Emergencies and Critical Care, Sociedad Argentina de Pediatría.

b. Pediatric Intensive Care Chapter, Sociedad Argentina de Terapia Intensiva.

c. Council of Certification for Training Programs, Sociedad Argentina de Pediatria.

d. Members of the Clinical and Epidemiological Research Group in Pediatric Intensive Care (see Annex 1 in electronic format).

E-mail Address:

Rodolfo Pablo Moreno,

M.D.: morenopablorod@ hotmail.com

Funding:

None.

Conflict of Interest:

None.

Received: 1-23-2015

Accepted: 5-11-2015

\section{INTRODUCTION}

The development of pediatric intensive care units (PICUs) has increased significantly in the past 30 years as a result of the combination of these factors: knowledge on the pathophysiology of critical patients, technological advances and biomedical engineering development, improvement in professional ethics, and healthcare providers' vocation for this specialty. ${ }^{1,2}$

The residency system is considered the best model that allows healthcare providers to reach specialization. ${ }^{3}$ With this intensive training model, health services become training institutions that play a double role: workplace and training place. ${ }^{4}$

Pediatric intensive care (PIC) residency programs have been in place in Argentina for just a few years. Knowing the status of PIC residency programs offers a possibility to establish strategies that allow to help with the development and training of healthcare providers who may provide the pediatric population with the care our society claims. In Argentina, there are no published studies on PIC residency programs.

\section{OBJECTIVES}

To describe the characteristics of PIC residency programs across Argentina.

To assess whether certain characteristics are related to a higher filling of assigned vacancies.

To assess job placement in the hospital where PIC residents are trained. 


\section{POPULATION AND METHODS Work methodology}

All PIC residency programs in Argentina were invited to participate through a letter submitted to the head of department describing the details of participation criteria, objectives, date of initiation and end of the survey, and operational definitions of outcome measures.

Authors were in charge of surveying residency programs, collecting data and contacting the different PICUs.

The extent of participation of heads of departments comprised data collection and submission to representatives of the Argentine Society of Pediatrics (Sociedad Argentina de Pediatría, SAP) and the Argentine Society of Intensive Care (Sociedad Argentina de TerapiaIntensiva, SATI).

\section{Design}

Descriptive, observational study. National survey.

\section{Inclusion criteria}

PIC residency programs functioning in Argentina in the survey period, between April $1^{\text {st }}, 2014$ and May 31 ${ }^{\text {st }}, 2014$.

\section{Definitions}

- Large-volume PICU: $\geq 8$ beds and $\geq 400$ annual hospitalizations. ${ }^{1,5-7}$

- Certification of residency program: a process for harmonizing training criteria and establishing a common base to ensure high-quality training across the country and providing common curricular guidelines. The National Certification System of Residency Programs of the Health Team is regulated by Ministry Resolutions no. 450/06 and 1342/07. 8,9 All jurisdictions adhere to this system and get approval from the Federal Council of Health.

- Job placement: an employment and/or fixed on-duty agreement.

\section{Survey design}

The survey was designed by the SAP's National Committee of Emergencies and Critical Care and the SATI's Pediatric Intensive Care Chapter based on the Residency Reference Framework with Specialty in Pediatric Intensive Care ${ }^{10}$ the Instrument to Assess Residency Programs, ${ }^{8}$ and the National Standards for Certification of Residency Programs. ${ }^{9}$

\section{Statistical analysis}

Continuous outcome measures were expressed as median and interquartile range (IQR). Categorical outcome measures were expressed as percentages and 95\% confidence interval $(95 \% \mathrm{CI})$ and compared using a $\chi^{2}$ test. A univariate logistic regression analysis was done to assess the relationship between independent outcome measures and the event of interest, followed by a multivariate logistic regression analysis. Outcome measures with a $p$ value $\leq 0.2$ in association with Wald test were selected to be included in the multivariate model, leaving those with AES (Wald test: $p<0.05$ ). The presence of confounding factors was assessed using an iteration process until all biologically and statistically irrelevant outcome measures were excluded. Effect sizes were reported as odds ratios (OR) with their corresponding 95\% CIs. The model's robustness was assessed using the Hosmer-Lemeshow test. Probable atypical values and potentially influential factors were also searched.

\section{Ethical aspects}

Collected data were accessed in accordance with all ethical and legal regulations (Act 25326). Collected data were not used for any other purposes, and the identity of PICUs was kept confidential by means of dissociation (coded or reversely dissociated data).

This study was approved by the institutional boards of participating hospitals.

There is no funding or conflict of interest to declare.

\section{RESULTS}

\section{Characteristics of participating hospitals}

Thirty-two PIC residency programs were invited to participate; 31 agreed and sent their reports. Of these, $87 \%(n=27)$ were public and $13 \%(n=4)$ were private. PICUs were distributed as follows: 14 pediatric hospitals, 12 general hospitals, and 5 mother and child hospitals.

\section{General characteristics of pediatric intensive care units}

Nineteen hospitals also had intermediate care units.

The median number of PICU beds was 10 (IQR: 8-15) (private: 9 beds, IQR: 4-13; public: 11 beds, IQR: 7-15). The median annual number of hospitalizations was 378.70 (IQR: 200-470). 
Eleven out of thirty-one PICUs were considered to be large-volume units ( $36.67 \%$; $85 \%$ CI: $0.18-0.55)$.

\section{Functional characteristics} of pediatric intensive care units

All PICUs admitted cases of medical, surgical and traumatic conditions.

Patients with severe traumatic brain injury were seen at 21 PICUs. The median annual number of neurosurgeries was 19 (IQR: 7-42).

Patients in the postoperative period of a heart surgery were hospitalized in 20 PICUs, and 15 admitted neonatal patients recovering from heart surgery. The median number of annual heart surgeries was 25 (IQR: 0-95).

Table 1 shows treatments provided at PICUs.

\section{Medical records}

Annual hospitalizations were recorded by 29/31 PICUs; 27 recorded data in a computerized system.

Variations in mortality associated with severity prognostic scores (PIM2 score) were assessed in $22 / 31$.

Table 1. Treatments used in pediatric intensive care units

\begin{tabular}{lc} 
Modality & Number of PICUs \\
\hline Conventional mechanical ventilation & 31 \\
High frequency ventilation & 24 \\
Pulse oximetry & 31 \\
Pulse oximetry ${ }^{(\#)}$ & 29 \\
Respiratory monitoring & 30 \\
Cardiac monitoring & 31 \\
Cardiac monitoring( ${ }^{(\#)}$ & 30 \\
Invasive BP(a) monitoring & 31 \\
Invasive BP(a) monitoring ${ }^{(\#)}$ & 27 \\
CVP(b) monitoring $^{(\#)}$ & 31 \\
Temporary external pacemaker & 28 \\
ECMO & 4 \\
Peritoneal dialysis & 30 \\
Hemofiltration & 14 \\
ICP(d) monitoring $^{(\text {) }}$ & 255 \\
\hline
\end{tabular}

PICU: pediatric intensive care unit.

(\#) Simultaneously in all PICU beds.

(a) BP: blood pressure.

(b) CVP: central venous pressure.

(c) ECMO: extracorporeal membrane oxygenation.

(d) ICP: intracranial pressure.

\section{Characteristics of residency programs}

The median time in the residency was 6 years (IQR: 4-15) and the median residency duration was 2 years (IQR: 2-3).

Dependence: 15 (48.39\%) provincial, 7 (22.58\%) national, $4(12.90 \%)$ municipal, 1 (3.22\%) university, $4(12.90 \%)$ private. Twelve out of thirty-one are the seat of the pediatric intensive care specialization career.

Distribution of residency programs: 8 in the province of Buenos Aires, 6 in the Autonomous City of Buenos Aires (CABA), 4 in Santa Fe, 2 in Córdoba, and 1 in each of the following provinces: Catamarca, Chaco, Corrientes, Entre Ríos, La Rioja, Mendoza, Misiones, Neuquén, Salta, San Juan, and Tucumán.

One of the residency programs (from the public sector) did not have a residency curriculum, and two did not have regulations in place. There were regulations and/or criteria for care in $9 / 31$.

Five of the residency programs were financed by the National Ministry of Health of Argentina.

\section{Admission}

A written exam was used in 30 PICUs; one of the private PICUs reported a different modality.

\section{Vacancies}

In 2013, there were 65 open vacancies; 61 corresponded to the public sector. The median number of annual vacancies per residency was 2 (IQR: 1-3).

Vacancies increased in the past four years, while vacancy filling rate decreased from 59\% in 2009 to $30 \%$ in 2013; some of the residencies were never able to fill their open vacancies (Figure 1). In the 2009-2013 period, 94 residents received training; $60 \%$ of these were then hired by the PICU where they were trained.

\section{Resident activities}

Distribution of weekly work load: $1^{\text {st }}$ year, median of 60 hours (IQR: 48-76); $2^{\text {nd }}$ year, 58 hours (IQR: 50-68); and $3^{\text {rd }}$ year, 51 hours (IQR: 40-62).

The distribution of activities performed by residents is described in Figure 2.

Monthly on-duty shifts (median): $1^{\text {st }}$ year, 6 (IQR: 6-7) (at 5 public PICUs, the median number was 8$) ; 2^{\text {nd }}$ year, 5 (IQR: $\left.5-6\right) ; 3^{\text {rd }}$ year, 4 (IQR: 4-6). At all PICUs, on-duty shifts are supervised by physicians specialized in pediatric intensive care.

No rest period was allowed following an on- 
duty shift in 11/31 PICUs, all from the public sector.

\section{External rotations}

Twenty-five residency programs offered external rotations. The departments chosen by residents included cardiovascular PICUs (19/25), other multipurpose PICUs (14/25), and burn PICUs (4/25).

FIGURE 1. Relationship between open vacancies and vacancy filling rate

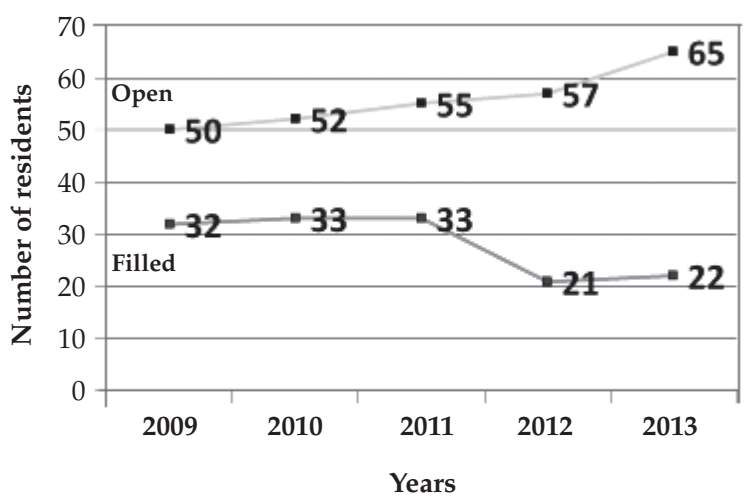

FIGURE 2. Distribution of residency program hours by activity

Health care activities

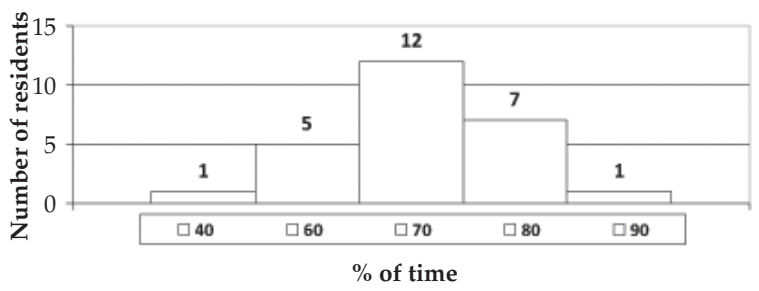

Teaching activities

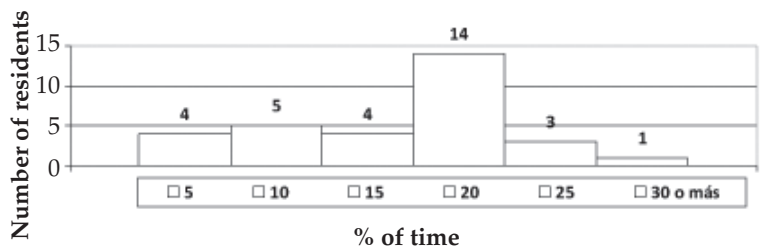

Research

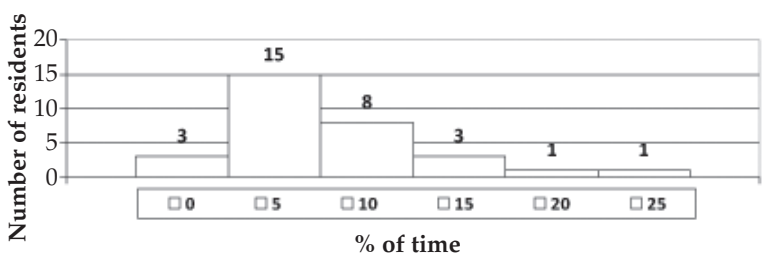

\section{Teaching}

There was a head of residents in $8 / 31$, and a resident trainer in 15/31. At $13 / 31$ PICUs (11 from the public sector, 2 private) there was neither a head of residents nor a trainer.

At 26 PICUs (83.87\%), there was a person in charge of the residency program, and at 25 $(80.65 \%)$ there were teaching physicians. The median number of teachers per department was 3 (IQR: 1-10). At 8/31 PICUs, teachers and/or those responsible for the program had received pedagogical training.

The program suited the national reference framework in 17/31.

All PICUs offered courses, in average, twice a week. Daily handoffs and shift handoffs were performed at all PICUs, always supervised by staff and/or on-duty physicians.

Bibliographic rounds were conducted in 28 PICUs (90.32\%); anatomical-clinical rounds, in 25 (80.64\%); and mortality rounds, in $15(48.38 \%)$. Medical histories were reviewed at 27/31 PICUs.

Critical reading courses were offered in 16/31; and all provided a course on cardiopulmonary resuscitation.

\section{Assessments}

Residents were assessed three times a year (IQR: 2-4). Type of assessment: 29 (93.54\%) had staff physicians and/or heads of residents perform direct observations, $26(83.87 \%)$ conducted written exams, $16(51.61 \%)$ conducted oral exams, and $15(48.38 \%)$ used checklists. Only 2/31 used the Objective Structured Clinical Examination (OSCE), and none used the Script Concordance test (SCRIPT) or the Mini Clinical Evaluation Exercise (mini-CEX).

At 25/31, an exam was administered at the end of the residency; procedures were recorded at $20 / 31$.

\section{Research}

Research was conducted at 24/31 PICUs. Only $1 / 31$ offered courses on research, and 19/31 had academic supervisors.

Only 8/31 published completed articles. Most were presented at hospital sessions $(n=16)$ and national conferences $(n=20)$.

\section{Employment framework in relation to residency programs}

At 11/31 PICUs, residents had medical malpractice insurance coverage, and at 26/31, they had occupational accident insurance 
coverage. Health insurance coverage was offered by 28 residency programs $(90.32 \%)$. Paid vacations, maternity leave, sick leave and leave to attend conferences were offered by $100 \%$ of PICUs.

A working uniform was provided by 8/31 PICUs.

\section{Predictors of vacancy filling}

A bivariate analysis was performed to look for outcome measures related to the outcome measure "vacancy filling rate $>60 \%$ ", defined as residency programs that managed to fill $>60 \%$ of open vacancies in the $2009-2013$ period. Statistical significance was observed among the outcome measures of interest of large-volume PICU $(p=0.001)$, research work $(p=0.012)$, medical malpractice insurance coverage provided by the funder $(p=0.010)$, and social security coverage $(p=0.032)$ (Table 2).

A multivariate logistic regression analysis was done to identify outcome measures that may serve as independent predictors of the outcome measure of interest "vacancy filling rate $>60 \%$ ". The model included outcome measures with a $p$ value $<0.2$ (annual hospitalizations $>400$, medical malpractice insurance coverage, research work, social security coverage, occupational accident insurance coverage, presence of a trainer, presence of on-duty staff physicians). The outcome measure "annual hospitalizations $>400$ " was identified as an independent predictor of vacancy filling rate $>60 \%$; the rest had a nonsignificant $p$ value and very wide confidence intervals.

TABLE 2. Bivariate analysis of vacancy filling rate $>60 \%$

\begin{tabular}{lc}
\hline Outcome measures & P value \\
\hline PICU $>400$ hospitalizations/year & 0.00 \\
Research work & 0.012 \\
Medical malpractice insurance & 0.010 \\
Social security coverage & 0.032 \\
Structured residency & 0.060 \\
Dependence(\#) & 0.084 \\
Presence of staff physicians & 0.069 \\
Certified head of department & 0.085 \\
Presence of a head of residents or resident trainer & 0.095 \\
Rest period following an on-duty shift & 0.297 \\
\hline
\end{tabular}

${ }^{(\#)}$ National, provincial, municipal.

\section{DISCUSSION}

Residency, as part of postgraduate training, merges knowledge and practice in the hospital setting and attempts to meet health care needs..$^{4,11}$ Residents have a double chance of learning, both from focusing in an area of knowledge and from working in the context of real situations and varying scenarios. ${ }^{4,12}$

In Argentina, there are 32 pediatric intensive care residency programs; most have few residents compared to the number of vacancies and the number of beds. This contrasts the situation of the United States, where there are 60 residency programs with an average of seven residents per facility. ${ }^{12}$ These data demonstrate that, in Argentina, the number of physicians under training may not be adequate.

The National Ministry of Health of Argentina recommends that each PICU should have, at least, six beds ${ }^{13}$ however, we found that certain PICUs have fewer than six beds and also observed a great variation in human and technological resources. Differences in the suitability of organizational structure, the distribution of residency programs compared to the number of physicians graduating in this area and system requirements should be studied. ${ }^{11} \mathrm{~A}$ challenge for the future will be establishing a homogenous training program across Argentina that determines minimal standards for professional characteristics suitable to the national reference framework. ${ }^{10}$

Most residencies have a curriculum, ${ }^{10}$ but it is worth noting that some residency programs have no curriculum or regulations in place. Our societies should make joint counseling efforts to ensure compliance with teaching goals across the program and not just limiting to resident participation in settings where there is a high demand for medical care. ${ }^{14,15}$

In the United States, pediatric intensive care residents spend $50 \%$ of weekly hours devoted to research. ${ }^{12}$ In the studied PIC residency programs, less than $60 \%$ offer courses or workshops on research, which is assigned a minimal work load. Residents not always perceive this as a shortage, ${ }^{16}$ as is the case of other aspects of current medicine, such as communication in complex situations or resource management.

A residency program requires health care activities to be supervised by trained staff, and teachers involved in the program are obliged to ensure that all residents learn the necessary skills to practice their specialty adequately. ${ }^{12,17}$ 
Performance evaluation aims at systematically demonstrating the achievement of results as expected in set goals. ${ }^{15,18}$ However, the analysis of residency programs shows a great variation, and this is another factor that requires future work in order to establish equivalent standards.

In terms of work load, pediatric intensive care residents in Argentina work more hours than in other Latin American countries, ${ }^{3}$ but less than in the United States. ${ }^{19}$ The Accreditation Council for Graduate Medical Education has recommended a reduction in resident duty hours, an increase in supervision and an approach based on patient safety. ${ }^{20,21}$ In France, resident duty hours were restricted to 52.5 hours per week. ${ }^{22}$ The National Ministry of Health of Argentina establishes that residents should work, at least, 48 hours per week and complete not more than eight on-duty shifts per month. ${ }^{4}$

There is evidence that an excessive work load and an inequitable distribution of duties lead to burnout ${ }^{19,23,24}$ and cause high rates of depersonalization and emotional exhaustion among residents. ${ }^{25,26} \mathrm{~K}$. E. Fletcher, et al. ${ }^{23}$ suggested that residents' quality of life may be improved by limiting duty hours; the impact of such reduction on education remains unknown. In Argentina, the prevalence of burnout affects $20 \%$ of residents..$^{24}$ In order to prevent burnout, working conditions should be improved, ${ }^{27}$ have an effective supervision in place, and allow for a rest period after on-duty shifts. ${ }^{2}$ However, pediatric intensivists receive no benefits in relation to patient safety, which may be attained by reducing resident duty hours. ${ }^{28,29}$

The number of vacancies filled in PIC residency programs has decreased in the past years. In our setting, there are other training programs in place: fellowship grants for specialization in PIC with academic university accreditation. Such postgraduate systems are offered even in certain PICUs whose residency programs were part of this study. These fellowships may potentially impact the reduction in vacancy filling rate; however, if there were enough residents interested in this specialty, all fellowship and residency vacancies would be filled. The lack of pediatric intensivists is a worldwide reality ${ }^{30-32}$ related to multiple factors.

The primary objective of the residency system should be to ensure training of physicians who will be capable of providing an excellent care to their patients and practice their specialty for a long time. ${ }^{33}$ Conclusions evidence the need to redirect human resource policies in the health area, particularly specialist training.

In spite of the essentially descriptive nature of this study, we are convinced that this type of studies is relevant to provide information that will allow to improve PIC training, facilitate decisiontaking in resource allocation based on local data, and confirm the importance of encouraging young physicians to select a subspecialty.

\section{CONCLUSIONS}

There is a great shortage in vacancy filling in PIC residency programs.

The number of residency programs certified by the National Ministry of Health is scarce.

PICUs with the largest volume of hospitalizations were associated with a better residency vacancy filling rate.

More than half of residents got a job in the PICU where they were trained.

\section{REFERENCES}

1. Namachivayam P, Shann F, Shekerdemian L, Taylor A, et al. Threedecades of pediatric intensive care: Who was admitted, what happened in intensive care, and what happened afterward. Pediatr Crit Care Med 2010;11(5):549-55.

2. RoqueJ.Cuidados intensivos pediátricos: pasado, presente y futuro. Rev Chil Pediatr 2013;84(3):249-53.

3. Organización Panamericana dela Salud.Área deSistemas de Salud basados en la Atención Primaria de Salud. Residencias médicas en América Latina. Washington DC; 2011.

4. Argentina. Ministerio de Salud. Dirección Nacional de Capital Humano y Salud Ocupacional. Sistema nacional de acreditación de residencias del equipo de salud. Normativa, guías y estándares a 7 años de su creación. Ciudad Autónoma de Buenos Aires; 2014.

5. Nipshagen MD, Polderman KH, DeVictor D, Gemke NJ. Pediatric intensive care: result of a European survey.Intens Care Med 2002;28(12):1797-803.

6. Odetola FO, ClarkSJ, Freed GL, Bratton SL, et al. Anational survey of pediatric critical care resources in the United States. Pediatrics 2005;115(4):e382-6.

7. Köro lu TF, Atasever S, Duman M. A survey of pediatric intensive care services in Turkey. Turk J Pediatr 2008;50(1):12-7.

8. Argentina. Ministerio de Salud. Dirección Nacional de Capital Humano y Salud Ocupacional. Instrumento de Evaluación de Residencias/2010. Buenos Aires, 2010. [Accessedon: March 2, 2014]. Available at: http://www. msal.gov.ar/residencias / images / stories / descargas / acreditaciones/adjuntos/instrumento\%20residencias\%20 2010.pdf.

9. Argentina. MinisteriodeSalud.DirecciónNacionaldeCapital Humano y Salud Ocupacional. Estándares Nacionales para Acreditación de Residencias. Buenos Aires, 2010. [Accessedon: March 2, 2014]. Available at: http://www. msal.gov.ar/residencias/images/stories/ descargas/ acreditaciones/adjuntos/estandares $\% 20$ nacionales $\% 20$ para \%20acreditacion \%20de\%20residencias. pdf.

10. Argentina. Ministerio de Salud. Sistema Nacional de Residencias del Equipo de Salud. Marco de Referencia para la Formación en Residencias Médicas. Especialidad 
Terapia Intensiva Infantil. Buenos Aires, 2013. [Accessedon: May 2, 2014]. Available at: http://www.msal.gov.ar/ residencias/images/stories/descargas/acreditaciones/ adjuntos/terapia_intensiva_infantil_mr.pdf.

11. Borrell Bentz RM. La educación médica de posgrado en Argentina: el desafío de una nueva práctica educativa. Buenos Aires: Organización Panamericana de la Salud; 2005.

12. Morrison WE, Helfaer MA, Nadkarni VM. National survey of pediatric critical care medicine fellowship clinical and research time allocation. Pediatr Crit Care Med 2009;10(3):397-9.

13. Resolución 747/2014. Directrices de Organización y Funcionamiento de las Unidades de Cuidados Intensivos e Intermedios Pediátricos en Establecimientos Asistenciales. Boletín Oficial de la República Argentina, Buenos Aires, Argentina, 22 de mayo de 2014.

14. Bowen KA, Ball TM. Pediatricians' evaluations of their residency curriculum in emergency medicine. Pediatr EmergCare 2003;19(2):79-83.

15. Busaniche J. La importancia de la evaluación de los residentes. ¿Qué, cómo y cuándo evaluar? Arch Argent Pediatr 2007;105(4):291-2.

16. Vázquez-MataG,Rodríguez-Elvira M,Rucabado-AguilarL, García-Alcántara A, et al. Los residentes en las unidades de cuidadosintensivos, ¿cuál es su percepción de la formación que reciben? Educ Med 2011;14(3):189-94.

17. Grenvik A, Schaefer JJ 3rd. DeVita MA, Rogers P. New aspects on critical care medicine training.Curr Opin Crit Care 2004;10(4):233-7.

18. Galli A, Castro C. Programa de formación de formadores en ciencias de la salud. Volumen III. Buenos Aires: Asociación Amigos de la Facultad de Medicina; 1999.

19. Blum $A B$, Shea $S$, Czeisler $C A$, Landrigan $C P$, et al. Implementing the 2009 Institute of Medicinerecommendations on resident physician work hours, supervision, and safety. Nat Sci Sleep 2011;3:47-85.

20. Nasca TJ, Day SH, Amis ES Jr. The new recommendations on duty hours from the ACGME Task Force. N Engl J Med 2010;363(2):e3.

21. Landrigan CP, Fahrenkopf AM, Lewin D, Sharek PJ, et al. Effects of the accreditation council for graduate medical education duty hour limits on sleep, work hours, and safety. Pediatrics 2008;122(2):250-8.

22. Woodrow SI, Segouin C, Armbruster J, Hamstra SJ, et al. Duty hours reforms in the United States, France, and Canada: is it time to refocus our attention on education? Acad Med 2006;81(12):1045-51.

23. Fletcher KE, Underwood W3rd, Davis SQ, Mangrulkar RS, et al. Effects of work hour reduction on residents' lives: a systematic review. JAMA 2005;294(9):1088-100.

24. Catsicaris C, Eymann A, Cacchiarelli N, Usandivaras I. La persona del médico residente y el síndrome de desgaste profesional (burnout). Un modelo de prevención en la formación médica. Arch Argent Pediatr 2007;105(3):236-40.

25. López-Morales A, González-Velázquez F, MoralesGuzmán MI, Espinoza-Martínez CE. Síndrome de burnout en residentes con jornadas laborales prolongadas. RevMedInstMex Seguro Soc 2007;45(3):233-42.

26. Mejía R, Diego A, Alemán M, Maliandi M, et al. Percepción de maltrato durante la capacitación de médicos residentes. Medicina (B Aires) 2005;65(4):295-301.

27. Gordon MB, Sectish TC, Elliott MN, Klein D, et al. Pediatric residents' perspectives on reducing work hours and lengthening residency: a national survey. Pediatrics 2012;130(1):99-107.

28. Freed GL, Dunham KM, Moran LM,Spera L. Resident work hour changes in children's hospitals: impact on staffing patterns and workforce needs. Pediatrics 2012;130(4):700-4 .

29. Typpo KV, Tcharmtchi MH, Thomas EJ, Kelly PA, et al. Impact of resident duty hour limits on safety in the intensive care unit: a national survey of pediatric and neonatal intensivists. PediatrCrit Care Med 2012;13(5):578-82.

30. Galván ME, Vassallo JC, Rodríguez SP, Otero $\mathrm{P}$, et al. Síndrome de desgaste profesional (burnout) en médicos de unidades de cuidados intensivos pediátricos en la Argentina. Arch Argent Pediatr2012;110(6):466-73.

31. Campos-Miño S, Sasbón JS, Von Dessauer B. Los cuidados intensivos pediátricos en Latinoamérica. Med Intensiva 2012;36(1):3-10.

32. Stromberg D. Pediatric cardiac intensivists: are enough being trained? PediatrCritCareMed 2004;5(4):391-2.

33. Peets A, Ayas NT. Restricting resident work hours: the good, the bad, and the ugly.Crit Care Med 2012;40(3):960-6. 


\section{ANNEX 1}

\section{MEMBERS OF THE CLINICAL AND EPIDEMIOLOGICAL RESEARCH GROUP IN PEDIATRIC INTENSIVE CARE}

María del Pilar Arias, M.D. Hospital General de Niños "Dr. Ricardo Gutiérrez", City of Buenos Aires, Argentina.

Amparo Baldironi, M.D. Hospital Pediátrico del Niño Jesús, Córdoba, Argentina.

Alberto Blanco, M.D. Hospital Pediátrico "Juan Pablo II", Corrientes, Argentina.

Ana Carola Blanco, M.D. Hospital Nacional "Prof. Dr. Alejandro Posadas", Haedo, Argentina.

Daniel Gustavo Bergna, M.D. Hospital de Niños (Interzonal de Agudos Especializado en Pediatría) "Superiora Sor María Ludovica", La Plata, Argentina.

María Alejandra Boretto, M.D. Sanatorio de Niños, Rosario, Argentina.

Carmen Colman, M.D. Hospital Pediátrico “Dr. Avelino Castelán”, Resistencia, Chaco, Argentina.

Pablo Eulmesekian, M.D. Hospital Italiano de Buenos Aires, Buenos Aires, Argentina.

Liliana Galleguillo, M.D. Hospital de la Madre y el Niño de La Rioja, La Rioja, Argentina.

Germán Kaltenbach, M.D. Hospital Provincial "Dr. Eduardo Castro Rendón”, Neuquén, Argentina.

Karina Fiquetron, M.D. Hospital de Alta Complejidad "El Cruce Néstor Carlos Kirchner",

Florencio Varela, Argentina.

Luis Folco, M.D. Hospital Público Materno Infantil, Salta, Argentina.

Macelo Itharte, M.D. Hospital Materno Infantil San Roque, Paraná, Argentina.

Walter Lorenz, M.D. Hospital Zonal General de Agudos "Lucio Meléndez", Adrogué, Argentina.

Liliana Luján, M.D. Hospital de Niños de la Santísima Trinidad, Córdoba, Argentina.

Lorenzo Marcos, M.D. Hospital del Niño Jesús, San Miguel de Tucumán, Tucumán, Argentina.

Marta Mosciaro, M.D. Hospital Pediátrico “Dr. Humberto J. Notti”, Mendoza, Argentina.

Rodolfo Pacce, M.D. Hospital de Niños de Santa Fe “Dr. O. Alassia”, Santa Fe, Argentina.

Alicia Panigazzi, M.D. Hospital Nacional "Prof. Dr. Alejandro Posadas", Haedo, Argentina.

Matías Penazzi, M.D. Hospital del Niño de San Justo, San Justo, Argentina.

Roberto Marcelo Pena, M.D. Hospital Municipal Materno Infantil de San Isidro

"Dr. C. Gianantonio", San Isidro, Argentina.

Javier Ponce, M.D. Hospital Público Descentralizado “Dr. Guillermo Rawson”,

San Juan, Argentina.

Graciela Rivello, M.D. Sanatorio Güemes, Buenos Aires, Argentina.

Graciela Romero, M.D. Hospital Interzonal de Niños "Eva Perón", Catamarca, Argentina.

María Gabriela Rodríguez, M.D. Hospital de Clínicas UBA “José de San Martín”,

City of Buenos Aires, Argentina.

Silvia Susana Sáenz, M.D. Hospital de Niños de la Santísima Trinidad, Córdoba, Argentina.

Mariam Sarli, M.D. Hospital Nacional “Prof. Dr. Alejandro Posadas”, Haedo, Argentina.

Gustavo Sciolla, M.D. Hospital Provincial de Rosario, Rosario, Argentina.

Ariel Segado, M.D. Hospital de Niños de Rosario "Víctor J. Vilela", Rosario, Argentina.

Jorge Selandari, M.D. Sanatorio Güemes, Buenos Aires, Argentina.

Marcelo Terebiznik, M.D. Hospital Interzonal General de Agudos "Eva Perón",

San Martín, Argentina.

Silvio Fabio Torres, M.D. Hospital Universitario Austral, Pilar, Argentina.

Alicia Yunis, M.D. Hospital Público Provincial de Pediatría "Dr. Fernando Barreyro",

Posadas, Argentina. 